\title{
The Royal Pilgrimage of the Goddess Nanda
}

\section{Introduction: the goddess and her pilgrimage}

Once every twelve years, when it is thought that some calamity has taken place because of the curse of the goddess Nanda Devi, a four-horned ram is born in the fields of the former king of Garhwal, an erstwhile Central Himalayan kingdom in north India (see map of Garhwal). This four-horned ram leads a procession of priests and pilgrims on the most dangerous and spectacular pilgrimage in all of India: a three-week, barefoot journey of one-hundred and sixty-four miles, during some of the worst weather of the year, at the end of the rainy season. The procession reaches Rupkund, a small pond located at an altitude of more than 5,000 metres, which is surrounded by human skeletons, and from there it goes yet further, to Homkund, the 'Lake of the Fire Sacrifice'. According to the faithful, the four-horned ram leaves the procession at that point and finds its way, unaided, to the summit of Mount Trishul.

As its name suggests, the Royal Procession is closely associated with the ruler of this erstwhile Himalayan kingdom: he attends its inaugural rituals, the bones that litter the shores of Rupkund are believed to be those of one of his ancestors, and the chief sponsor of the event is a local 'Prince' who is thought to be descended from the first kings of Garhwal. This Prince traverses the domain of his ancestors and thereby lays claim to it in the name of the goddess Nanda, who is not only his lineage goddess but was also the royal goddess of the neighbouring kingdom of Kumaon, in pre-colonial times.

Although the Royal Procession ideally fosters social integration, it was disrupted in 1987 by a quarrel between two factions of priests. The goddess's itinerary, the culminating date of the pilgrimage, the type of sacrifice to be performed, the order of procession, the participation of previously excluded persons, and the competency of certain ritual specialists-all were subjects of heated dispute between the rival groups.

What was the reason for this quarrel? Participants told me more than once that the whole idea of the Progress was to create unity, yet in the event they were torn apart by an acrimonious dispute. So why were they quarrelling if it was 'only' a ritual, a matter of mere symbols? Although we often distinguish 
between the realms of 'politics' and 'ritual', and although many social scientists would balk at the idea that they are one and the same, I want to argue that in many cases, they pervade each other: ritual is politics and politics is ritual.

One of the main political effects of Nanda Devi's processions is to define specific units of territory. The Royal Procession is not the only local procession of Nanda Devi: there are also a number of one-day processions that typically join only a few villages together, and there are also larger processions lasting one to two weeks. But the Royal Procession occurs but once in a generation, and it is more demanding, costly, and spectacular than any of the smaller, annual processions. It traverses the largest unit of territory, and by traversing it, it defines it.

The relation between the goddess and the king is an ancient one. For more than a thousand years, the goddess Nanda was intimately associated with the rulers of the central Himalayas. The most ancient local dynasties attributed their good fortune to her, and local kings gave her gifts of land right up to

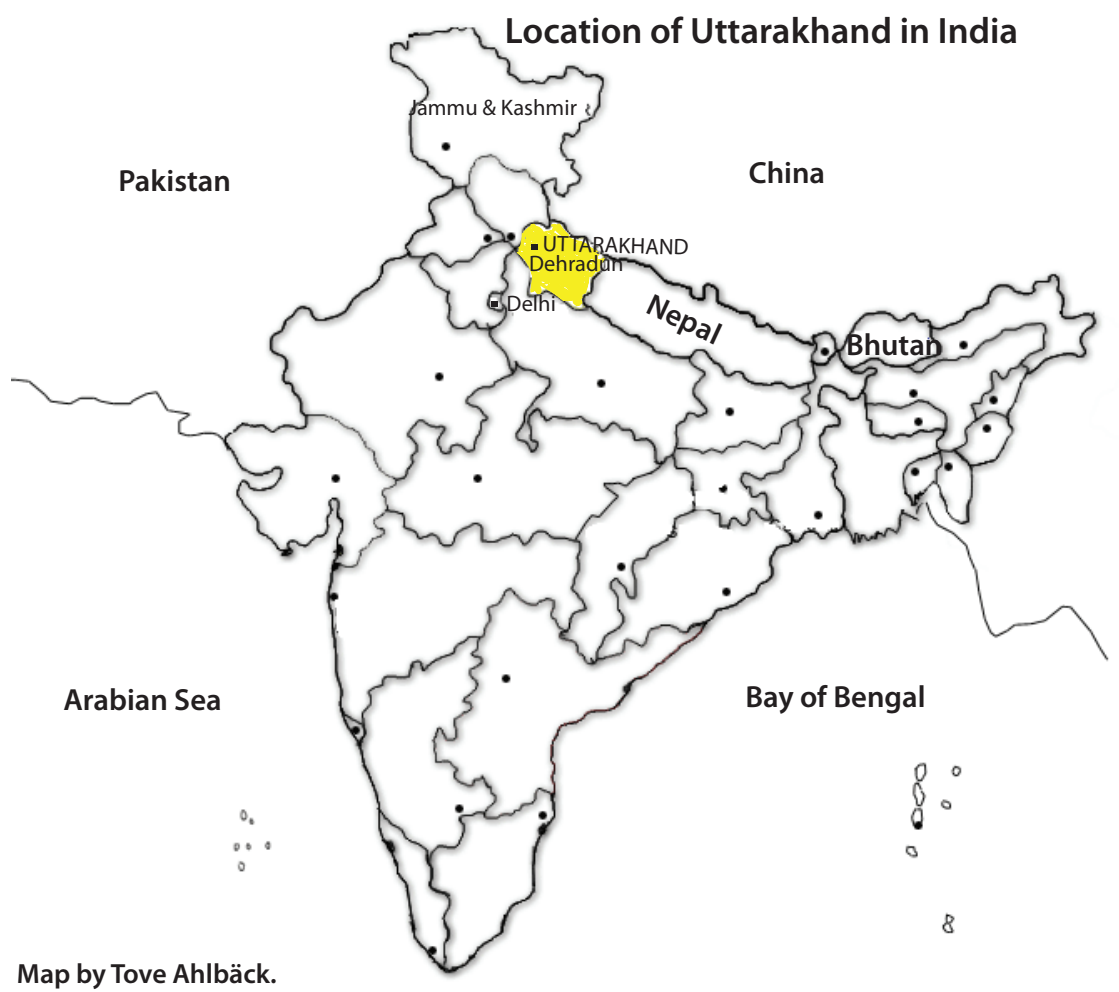


the modern period. In the seventeenth century, the king of neighbouring Kumaon stole a famous Garhwali idol of Nanda Devi, believing that possession and worship of it would guarantee his victory over the Garhwalis. Later on, the Kumaoni armies' battle-cry was 'Victory to Nandadevi!' (Atkinson 1974, II: 566; Sax 1991: 167-8). It is difficult to know just how old this tradition is. One of the rulers of the earliest known local dynasty, the Katyuris, already styled himself the paramabhakta or 'greatest devotee' of Nanda Devi in the mid-ninth century (Kielhorn 1896: 179, 183; Sircar 1956: 179, 282, 287-8). The Devi Purana, which Hazra (1942: 9) dates as 'no later than 850 a.d.', describes a local geography of pilgrimage that may well incorporate the pilgrimage (Hazra 1962: 351). And there are inscriptions in nearby temples dating between the eighth and tenth centuries, which suggest that at that time, at least some ascetics were committing acts of ritual suicide to Nanda Devi (Sircar 1959: 253; cf. Dabaral 1965-78, III: 477). But whatever the antiquity of the tradition, it is clear that a succession of kings, genealogists and priests believed that the power of the king flowed from the goddess Nanda, and this sort of royal goddess cult is quite common in India, where Hindu rulers have frequently attributed their military success and economic prosperity to their tutelary goddesses, who are embodiments of shakti, or female energy and brilliance.

But just as worship of Nanda Devi brings about success and prosperity, so ignoring her brings about failure and catastrophe. Indeed the Royal Procession is motivated by a 'curse' or 'blight' that she inflicts upon her natal kingdom of Rishasau when she is ignored. Here is an excerpt from my translation of the local song that explains the reasons for her pilgrimage:

The Goddess's curse lies heavy on Rishasau.

In Rishasau town, a bad time has begun.

The cows that they breed bear buffalo calves, the buffalos they breed bear tottering cow calves.

Their cows have no milk, their minds have no spark, their fields have no grain, their kingdom has no wealth.

The twelve old sages got very concerned.

The twelve sages' formal assembly convened.

The twelve elder sages said: 'Whence comes this curse?'

They summoned a Brahman from faraway Gaya, they summoned a scholar from the city of Kashi.

The pandits thus summoned then counted and asked, and found that the curse came from Nanda Devi, that girl Nanda who lives on Kailash. 
In order to restore prosperity and harmony, the king is compelled to lay on a feast for Nanda Devi and escort her back to Mount Kailash, and this is the origin of the Royal Procession. It begins at Nanda's temple in Nauti village in Chandpur, and is organized by the Nautiyal Brahmans of the same place. Because geographical factors are so important in my analysis, I shall henceforth refer to the Nautiyals as 'Lowlanders'. The Lowlanders base their authority to manage the Royal Procession upon their relation to the kings of Garhwal. They claim descent from one of twelve Brahmans who were settled by the dynastic founder in twelve villages around the old fort in Chandpur. The castes descended from these twelve are collectively known as the Twelve-Place Brahmans, and are the highest-ranked local caste. Because the Lowlanders served as royal gurus or religious preceptors of the king, they are first among the Twelve-Place Brahmans, and are thus the highest-ranked caste in Garhwal. Once every generation, each of the Twelve-Place Brahman lineages chooses a representative, who takes up a bamboo parasol, and joins the Royal Procession at a predetermined point in Chandpur. During the three weeks of the pilgrimage, the procession is led by the mysterious four-horned ram, regarded as an incarnation of the goddess, herself the source of royal power. The ram is followed by the Royal Parasol, a symbol of the king and his descendant the Prince. Next come the parasols of the Twelve-Place Brahmans, followed by hundreds of pilgrims, most of whom are farmers of the dominant local caste. Drummers from the lowest castes also accompany the procession as far as the final village of Bhala, thereby completing an assemblage that represents all the castes in Garhwal. If ever there was a Durkheimian 'collective representation', this is it: a representation by society, of itself, to itself. In this public, ritual event, the entire society publicly defines itself, so that the order of procession has very definite political implications. Similar processions have taken place throughout South Asian history. In medieval India, Hindu kings 'took possession' of their realms by processing to their borders (Gupte 1919: 180-3; Underhill 1921: 56-7), and the famous Perahära procession of Sri Lanka still summarizes the kingdom's social, political, economic, and religious systems (Seneviratne 1978). In a similar fashion, the Royal Pilgrimage takes possession of the land for Nanda Devi, and in so doing, it re-creates and re-unites the old kingdom in which the social system of Garhwal originated.

The Royal Procession is, however, clearly distinct from Nanda Devi's smaller, annual processions. Several of these occur inside the boundaries of patti $^{1}$ that were formerly included in the kingdom-and here, too, the pro- 
cessions define these districts by circumambulating their borders. The longest and best known of these smaller, annual processions is the annual 'Small Progress' of Nanda of Pratyeka patti. The Small Progress begins in the village of Thal, and traverses the patti. The priests of this procession were the core of one of the two opposing factions in the Royal Procession of 1987; the Lowlanders of Chandpur were the other. I shall refer to the Thal Brahmans and their allies from Pratyeka as the Highlanders.

Geography is important in several ways here, as is illustrated by the map. To begin with, both pilgrimages share a geography that is charged with mythic significance. From Jogmaya to Bedani, they both move along a path that was the site of Nanda Devi's battle with the buffalo demon - this is one of the most powerful and well-known myths in all of Hinduism, perhaps best-known as the story of Durga's defeat of Mahishasura as told in the Devi-Mahatmya. But in the pilgrimage, this pan-Indian myth is clearly localized: not only does it occur in local places, but it is related to the local system of kinship. Chandpur is considered to be Nanda Devi's natal place, and Pratyeka is her husband's place. The Lowlanders and their fellow-pilgrims from Chandpur are Nanda's natal relations, while the Highlanders and others from Pratyeka are her 'husband's people'. The dispute in the 1987 pilgrimage began only after the Royal Procession crossed the border between Chandpur and Pratyeka.

Geography, kinship and mythology are so inextricably intertwined here that it hardly pays to disentangle them. The Royal Procession of the Lowlanders begins in Chandpur near the old fort of the original king of Garhwal, whereas the Small Progress of the Highlanders begins in the politically insignificant village of Thal and traverses only one district. The Royal Procession uses vegetarian worship, while the Small Progress includes buffalo sacrifice. The Lowlanders derive their authority from the king while the Highlanders derive theirs from their relatively low-ranking occupation as priests. And finally, the lowlanders are thought of as the natal relations of the goddess Nanda, while the Highlanders consider themselves the people of her husband, Shiva.

In 1986, these distinctions were the basis of a bitter factional dispute. This dispute was only the latest episode in a long rivalry between the Lowlanders and the Highlanders. I haven't the space to describe it fully in this chapter, but in effect it comes down to three factors. First of all is the matter of caste: although the Highlanders belong to the highest varna-that of Brahman priests-they are ranked rather low within it. The Highlanders consume meat and liquor, allow brideprice and the remarriage of widows, and perform animal sacrifice, while the Lowlanders are vegetarian, abhor the remarriage of widows, and are prominent crusaders against animal sacrifice. All of these 
customs mark the Highlanders as 'backward' and 'low' in contrast to the Lowlanders, who are thought of as progressive and urbane. The two groups are also class rivals, since many Lowlanders are professionals and government servants, while the Highlanders follow less prestigious occupations such as farming and being priests. Nevertheless-or perhaps precisely because of these differences - the Highlanders cling to their exclusive authority as priests of Nanda Devi. They insist that only they may touch her image, and they deny this privilege to the proud Lowlanders. In short, they claim to have sole authority as priests of Nanda Devi, and in the 1987 Royal Procession, they asserted this claim against the Lowlanders.

For their part, the Lowlanders publicly and loudly criticize what they call the 'uncivilized' and 'unlearned' customs of the Highlanders, especially animal sacrifice. Several years ago, they invited the Highlanders to a festival in Chandpur. They paid for the Highlanders' bus tickets, food and lodging-and all of this was done in order to 'educate' them in the virtues of vegetarian worship. There was a public row, and the mutual resentment of the two groups increased.

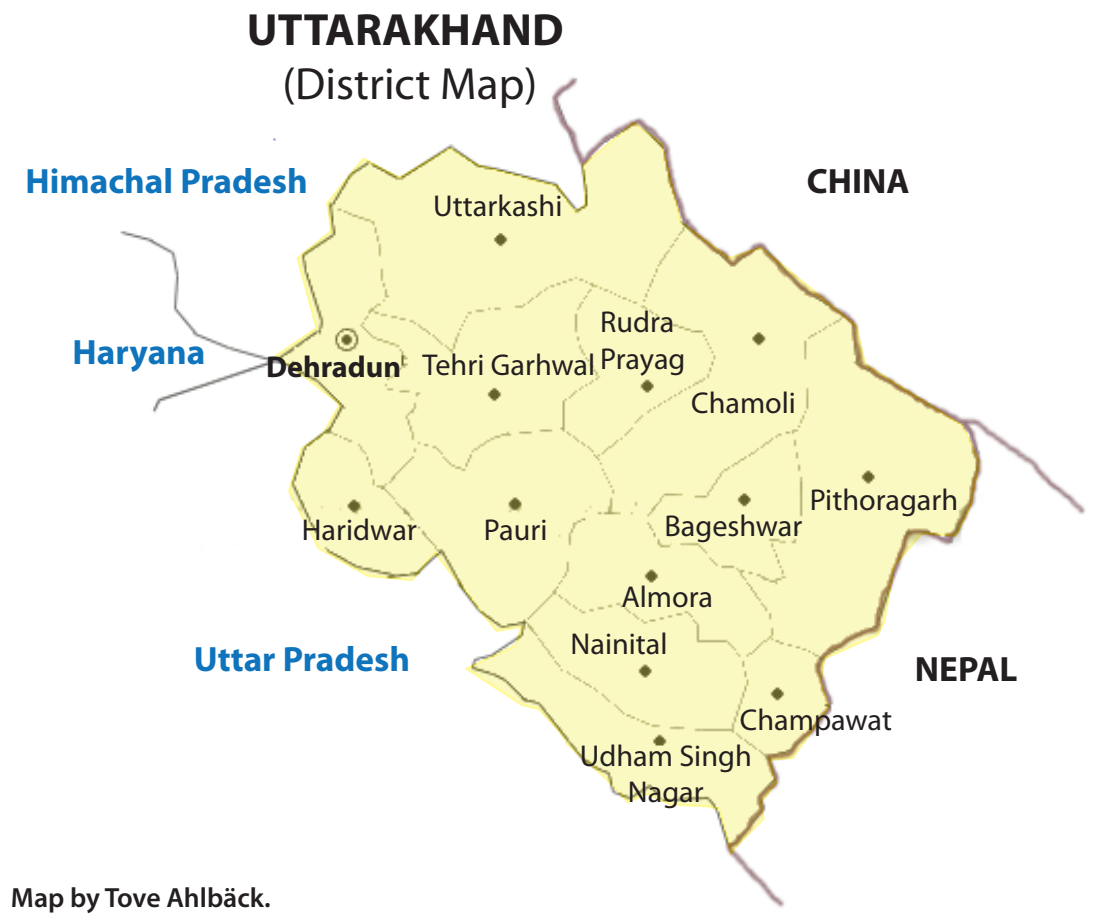


Schematic map of Nanda Devi's pilgrimages in Uttarakhand (Sax 1991: 48).

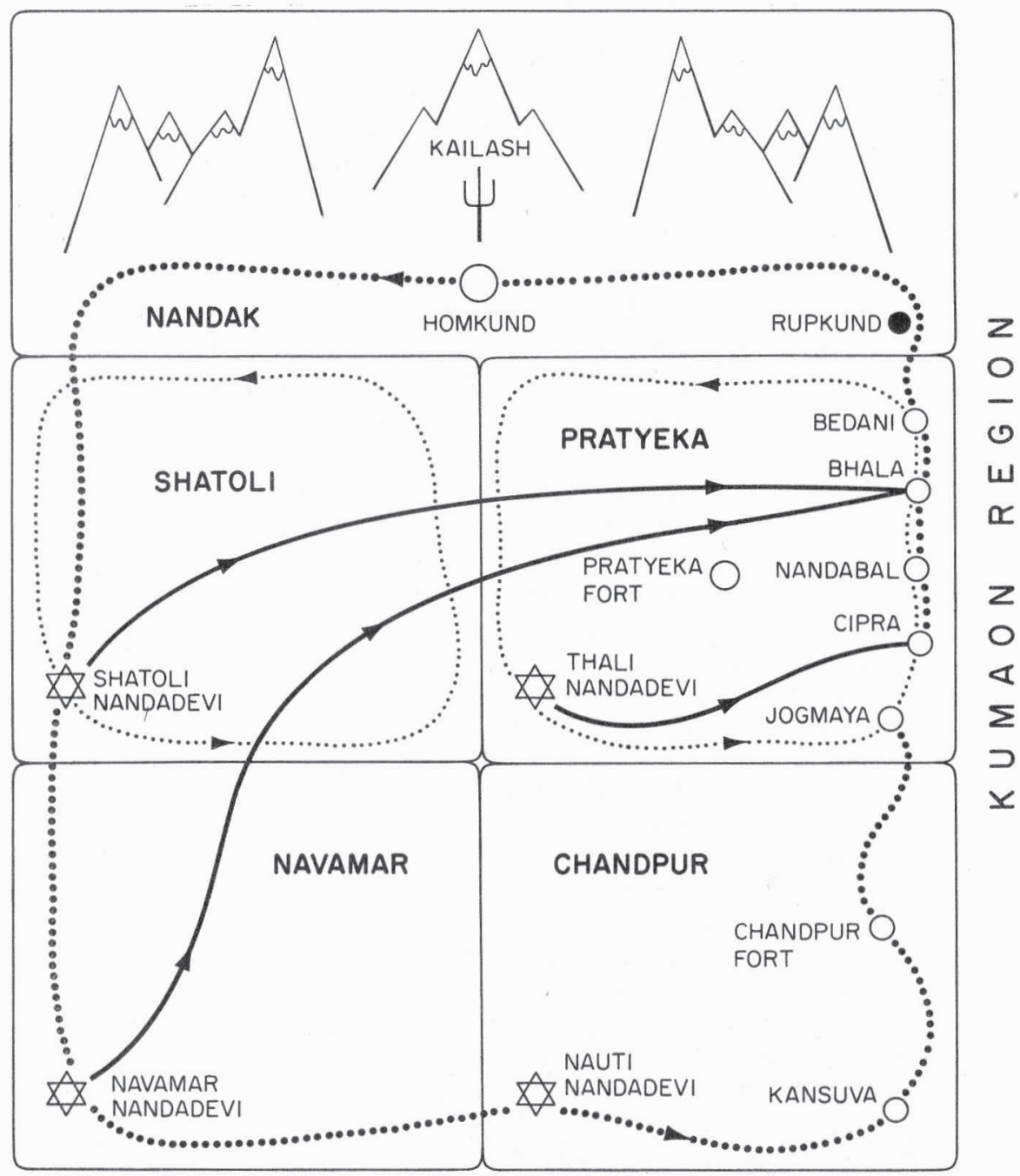

Schematic Map of Nandadevi's Pilgrimages in Uttarakhand

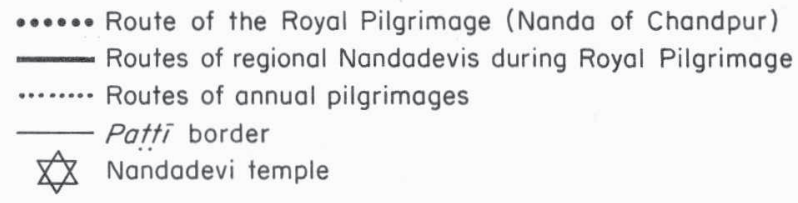


In 1986, when it was certain that the Royal Procession would occur, both groups began to use the local media as a forum for their dispute. In a series of articles and letters to the editors of local newspapers, the Highlanders complained that they had been excluded from the deliberations of the Royal Procession Committee and that no funds had been spent in or near their own village. They alleged that certain 'big-shots' among the Lowlanders had perverted the Royal Procession tradition for their own ends, and they even threatened a lawsuit. Later, the Highlanders distributed a poster in which they promulgated a separate programme for the Royal Procession. According to the new itinerary, their own Nanda Devi, the Nanda of Pratyeka, would lead the procession, which would conclude a day later than had been planned, and she would be worshipped by means of animal sacrifice. In effect, the Highlanders were claiming authority to determine the itinerary, dates, and forms of worship, something for which the Lowlanders had always been responsible in the past. The Lowlanders' response was quite restrained, and this may have a crucial mistake. Perhaps they did not take the Highlanders' challenge seriously; possibly they saw a new opportunity to humble their rivals; in any event they merely drafted a letter, asking the Highlanders to abide by the programme that had already been decided, at a meeting that had in fact been attended by two of the Highlanders' representatives. 'The committee insists', they wrote, 'that you kindly give your whole-hearted support to this Great Pilgrimage.' But this was a vain hope.

\section{The 1987 Royal Procession}

The Royal Procession was inaugurated in the autumn of 1986, when the Prince, ${ }^{2}$ regarded as a descendant of the former King, fashioned a silken parasol and took it to the temple of Nanda Devi in Nauti. He asked the goddess's permission to do the pilgrimage. After that came two omens that convinced local persons that Nanda's curse had fallen. First was the miraculous birth of a four-horned ram, which is regarded as an incarnation of Nanda Devi herself, and is treated with great reverence. Second was a drought-the worst to have hit India in decades. Because these events happened after the Prince had

The adhyaksh or 'chairperson' of the Royal Procession Committee is always a member of the Kunvar caste, from the village of Kansua near the old fortress in Chandpur. He is regarded as a descendant of the king, and has final responsibility for the organization and successful completion of the Royal Procession. I refer to him here as 'the Prince'. 
made his formal request for the Royal Procession, everyone was convinced that the curse of Nanda had taken effect.

Everyone came for the Royal Procession. Journalists from near and far materialized with still cameras, audio recorders and video cameras. A cabinet minister arrived by helicopter, and the four-horned ram showed up in a chartered taxi. Two men in their nineties walked all those icy miles barefoot, and young hiking-clubbers clambered in from Calcutta festooned with the latest high-altitude equipment. A private filmmaker from Bombay followed the four-horned ram all the way from Nauti to Rupkund, and many local farmers brought rams that were sacrificed in the heights, and did not return. High and low, rich and poor, politicians and pilgrims, goddesses and demons, they were all there. Even the rains came on schedule: ten minutes after the procession left Nauti on the first day, it was inundated by the fiercest rainstorm of the summer, one that was badly needed in that year of drought.

Led by the Royal Parasol, the Lowlanders left Nanda's temple for the Prince's village about ten kilometres away, where the four-horned ram was waiting. Next morning we crossed a river, and handed the parasol over to a new group of priests, who carried it the rest of the way. One young man carried it most of the time. He was Nanda Devi's oracle, and much of the time he was in a state of trance. Villagers would approach the parasol and the oracle would begin to tremble and shake; then someone would lift him onto their shoulders and he-I ought to say, 'she', since it is thought that at this point Nanda Devi herself was speaking-would bless her devotees, answer their questions, and so forth. The oracle's stamina was remarkable. He was clothed very lightly, he was barefoot, he ate a very light meal only once each evening, and yet he remained possessed by the goddess for several hours each day, in the sun and in the pouring rain. At higher elevations there were, in addition to this priest, perhaps fifty or seventy-five other oracles, associated with numerous local deities, in our procession of several-thousand pilgrims.

Along the path we were joined by twelve more parasols, which represented the Twelve-Place Brahmans who were settled in the area by the original king of Garhwal. We processed for weeks, from village to village. In some places the procession would halt for ten or fifteen minutes, just time enough to receive offerings and give blessings. Elsewhere we would stop for one or two hours, and be feasted by the villagers, though of course the children always ate first.

For the first week, everything went smoothly. But as we drew nearer to the Highlanders' territory of Pratyeka, rumours began to circulate that the four-horned ram had died and a false one had been substituted for it. When 


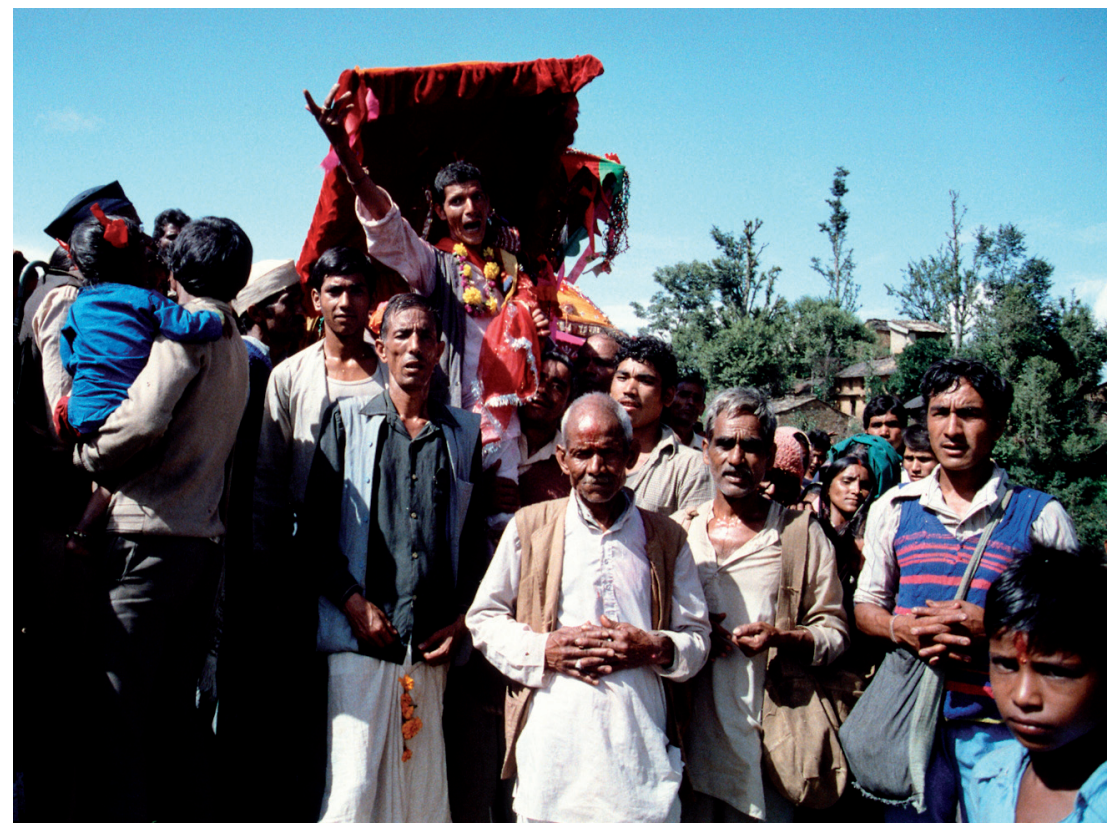

The Lowlanders' oracle of Nanda Devi. Photo @ William Sax.

Nanda Devi reached Jogmaya a local Prince, the opposite number of the Prince of Chandpur, prostrated before her, lifted her onto his head in a sign of submission and carried her to the temple, followed by a cheering throng of villagers.

However, the mood quickly changed. Several Highlanders had come, demanding that the procession be delayed a day, and that a buffalo sacrifice be performed. During the Royal Procession, and only during the Royal Procession, a geometrical representation of Nanda Devi called a yantra is unearthed on kalaratri, the 'night of death'. This yantra represents Nanda Devi in her fierce form as the blood-drinking goddess Kali, and traditionally a buffalo was sacrificed to her in this form, but blood sacrifice of this kind is now fiercely opposed by the Lowlanders.

The Prince of Chandpur was quickly surrounded by a group of angry Highlanders, but he continued to insist that they would offer no living being to Nanda Devi. Finally the crowd desisted. 'The curse has fallen on them', they said, 'not us. Let them do as they wish.' However, the Lowlanders were informed that arrangements for their food and lodging in the days ahead would be cancelled. One of the Prince's advisors took him aside, and warned him 
that from that point on, he should take care of three things: the four-horned ram, the Royal Parasol, and himself.

Soon the bazaar was buzzing with the news. I drifted from conversation to conversation, eavesdropping on the debates taking place in the street. One of the Lowlanders said, 'The Highlanders are only interested in two things: meat and liquor', to which a Highlander replied, 'Now you'll get your comeuppance-just try and proceed without our permission.' I spotted two of the Lowlanders' leaders walking down the street, and asked what was happening. One of them grasped my elbow and led me to a small shop where their priests were sitting. They listened forlornly as their leader explained the situation. When he was done, he looked at the head priest and said they would depend on the goddess to tell them what to do.

The priest began to beseech the goddess. 'Show us the way, Devi, show us the path, tell us what should be done!' Nanda Devi began to come over her oracle, who trembled and shook uncontrollably, growling with rage. Though I had seen many such trances, this one was particularly electrifying. 'Go!' shouted the priest. 'On to the temple! Show us the path, Devi! If you want animal sacrifice, we'll give it; but if you don't want it, we won't offer it!' Someone rolled up the aluminium storefront and the Lowlanders spilled into the street, first walking and then running behind their goddess, toward the temple.

When we arrived, the crowd parted like a wave. The Prince saw his goddess coming, and called out above the heads of the crowd 'Oh Devi, I'm taking you to Mount Kailash! I am under your protection! Tell me what to do!' Growling furiously, the goddess approached the temple where the Prince and the local priest were waiting. 'I am Kali!' she screamed, 'I am Kali! There will be no sacrifice!' And then something happened that I had never witnessed before. Leaning casually against a pillar in front of the temple, silhouetted against the lamps glowing within, the local priest said in a bored voice, 'This is a fake. Kali doesn't come on him. Get out. You have no place here. I am also Kali. I, too, am Kali.'

It was a standoff, but no one was prepared to back down. Finally, the Lowlanders broke with custom by appointing their own priest rather than the local one, and the Prince asked the crowd to join them in vegetarian worship. Having failed to obtain the cooperation of the local priest, the Lowlanders were unable to excavate the yantra.

Next day the Lowlanders arrived in the ancestral village of the Prince of Pratyeka, where both they and the Highlanders were planning to spend the night. My own feelings were highly ambivalent at this point, because I was quite close to some of the Highlanders. When I had last seen them, we had 
parted with the sentimental proverb varsom ki bhet, kedar ki jat ('A reunion after years, a pilgrimage to Kedarnath') - which means that it is as fine and rare to meet a friend or loved one after years of separation, as it is to do a pilgrimage to the temple of Kedarnath, pictured high in the Himalayas, and now I was standing in this dusty mountain town, waiting to be reunited with my dear friends the Highlanders-and they were locked in a bitter struggle with the Lowlanders, who were my oldest and most reliable allies in India!

Some men from the bazaar came running, rounding the corner down the road, and shouting that Nanda of Pratyeka was about to arrive. The drums preceding her palanquin were growing louder. One of the Lowlanders took me aside and said that I had best talk to my friends the Highlanders, and convince them to settle this dispute. In all of Garhwal, he said, there was no other person who could be trusted to be impartial, who was on good terms with both sides. This was too much for me; it violated all my ideas about 'objective' research, and I felt panicky. 'Wait a minute, I said. 'What can I do? I'm here only to observe!'

But our conversation was drowned out by the din of Nanda Devi's drums and bugles. People were rushing down the cobblestone path from above, clambering up from the rocky riverbank below. The Highlanders were determined to show the Lowlanders the depth of their popular support-after all, this was their territory - and they succeeded. Nanda Devi's palanquin lurched and heaved atop the shoulders of its bearers; it seemed as if it were about to burst with hot, angry energy. The crowd had swollen to large proportions in a scant few minutes; they showered Nanda Devi with flowers and supplications as they jogged alongside her up the hill toward the Prince's home. I spotted my friends the Highlanders and we embraced, even as we struggled to keep up with Nanda Devi's palanquin. She danced briefly in the courtyard, and then I went inside for an affectionate reunion with my old friends the priests. In the midst of our conversation - and quite unexpectedly-the Lowlanders' oracle stepped out of the shadows. In an emotional voice choked with tears, he began to speak:

I realize that I am younger than most of you. You could be my fathers, my uncles or elder brothers. So please pardon my boldness, and do me the kindness of listening to what I have to say. [We must all ask ourselves if this dispute will benefit any of us. Nanda] is our goddess but it's also possible that she may cease to be ours, if we do not behave properly and if we don't do the pilgrimage well. 
There was grunting and hissing from the shadows beyond the alcove. A fierce deity was taking possession of one of the priests. The priest began to sob and wail as he spoke:

And O Devi, I am your devoted worshiper. . .even though I am only twenty-six. . .still I've been worshipping you for years. . .I worship you with all my heart and so far I've had no trouble. . We should do the pilgrimage properly and it will be successful. . .

The deity lashed out: 'On the ninth, on the ninth!' but the priest continued:

If we go together our humanity will remain, but if we go as enemies, it won't remain. Perhaps you'll go on the ninth and we'll go on the eighth but, O Mother, if you have shakti, you show us the way!

From behind, someone called out 'Sacrifice him, sacrifice him!' and they dragged the hapless priest into the courtyard. Suddenly, and seemingly out of nowhere, the Prince of Chandpur arrived, alone and unprotected. In a calm, measured voice he said 'I am the Chairman of the Royal Procession Committee.' By this time, the Highlanders' Nanda had come over her oracle. She sat atop the shoulders of one of her devotees, head swathed in a brilliant red scarf, an iron dagger clenched between her teeth (see photo, p. 347). She removed the dagger and waved it about while addressing the Prince:

My tradition is. . Bedani Pond on Nanda Seventh, my tradition is. . . Homkund on the Ninth. . According to tradition the Pilgrimage (will conclude) on the ninth. Is there anything else? Speak! Speak the truth!

But the Prince was not persuaded. He stood resolutely before the goddess. He was told to hold up his hand, palm outward facing the oracle, to catch barley seeds that she would hurl at him in a common rite of augury (interpretation depends on the number of grains caught). He held up his hand but, in a stroke of theatrical genius, he didn't close his hand or catch any seeds. The oracle hurled two or three fistfuls of barley at the Prince's out-turned palm but they bounced off as he stood there, impassively. Then he began to speak, and the assembled crowd grew quiet: 'Listen to me everyone: I want to see both goddesses dancing together. And their decision will be binding.' A moment of silence followed, then someone said, 'Yes. The reunion will be tomorrow.' 
But there was no reunion the next day, nor the next, nor the day after that. Every attempt to reconcile the two factions came to nothing, and they grew increasingly hostile. Dramatic scenes like the ones I have described were repeated daily. In one village, a local god attempted forcibly to prevent the Lowlanders' oracle from proceeding; he actually seized her sari, and only cooled down after a police officer threatened to arrest him.

After a week of constant tension we reached the village of Bhala, where we were joined by the Nanda Devis of Shatoli and Navamar, both of whom had been carried on bridal palanquins from their respective districts, along with hundreds of other local gods and goddesses. Now the big question was: who would side with the Highlanders, and who with the Lowlanders? After several more oracular exchanges of the type that I have already described, both the newly-arrived Nanda Devis, along with their entourages of priests, pilgrims and oracles, and most of the other local gods, decided to accompany the Lowlanders and their goddess on the Royal Procession. The palanquins of the three Nanda Devis, the Royal Parasol and the parasols of the TwelvePlace Brahmans, and hundreds of gods, pilgrims, trekkers and journalists left the village of Bhala, proceeded into the rocks above the treeline, and left the Highlanders behind. Having failed to achieve their object, the Highlanders waited until we had left, concluded their pilgrimage at Bedani Pond, then

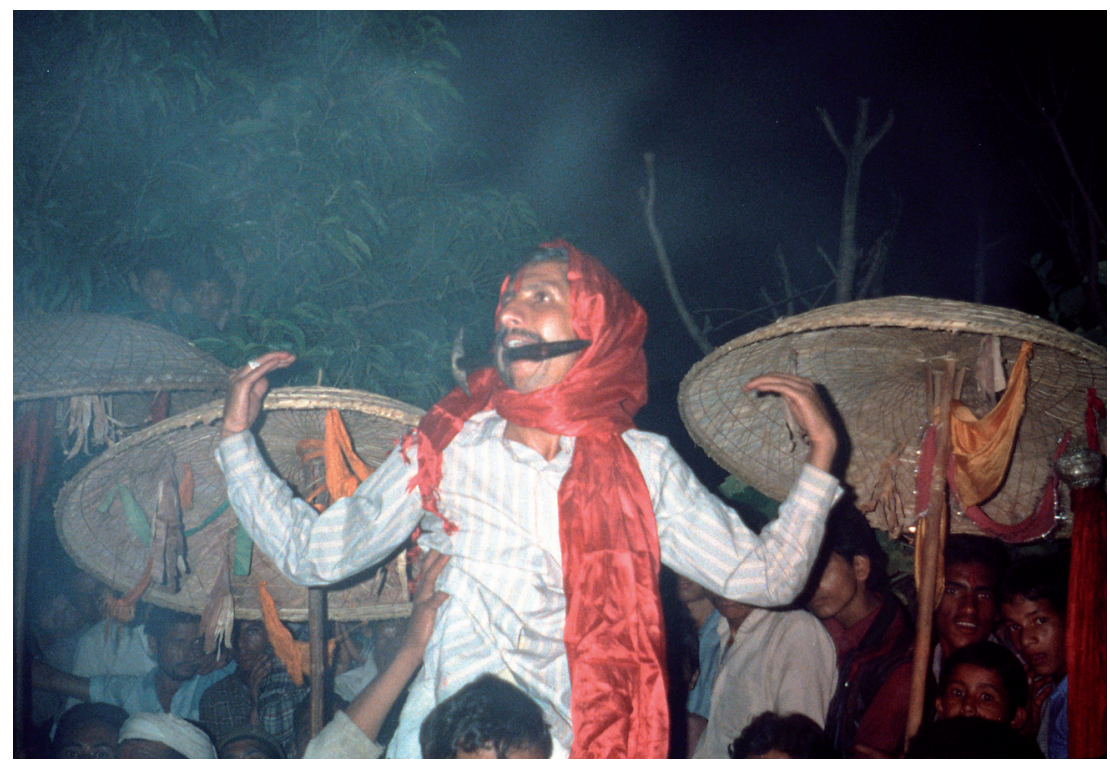

The Highlanders' oracle of Nanda Devi. Photo $\odot$ William Sax. 
turned around and went home, just as they do every year. The Lowlanders on the other hand performed an ancestral ritual at Bedani pond for the 'martyrs' of Rupkund, and later that night they bivouacked on a razor-sharp ridge at 13,000 feet above sea level. Many pilgrims turned back when they realized the hardships to be endured over the next four days, but most remained to rise next morning and climb several steep miles to a ridge from where the mighty chain of the Himalayas could be seen, shining under a brilliant, cloudless sky. It had rained every day until then, so that the pilgrims attributed the fine weather to the mercy of the goddess.

Then we plodded up the valley toward Rupkund, stopping every two or three minutes to gasp for air. The local legend of the origin of the bones at Rupkund is fascinating, but too long to repeat here. The crux of the matter is that they are said to be the bones of another Royal Procession party that defied Nanda Devi's rule against female participation, by bringing women along. Not only that, but they brought a pregnant woman-the queen herself-who polluted the pure heights of the Himalaya with vaginal blood by giving birth to a daughter during the pilgrimage. They had thus triply violated the injunction against women, by bringing dancing girls, and a pregnant queen who gave birth to a daughter. Nanda Devi was furious, and sent down a storm of 'iron-like hail'. The army and pilgrimage party were sucked into a whirlwind

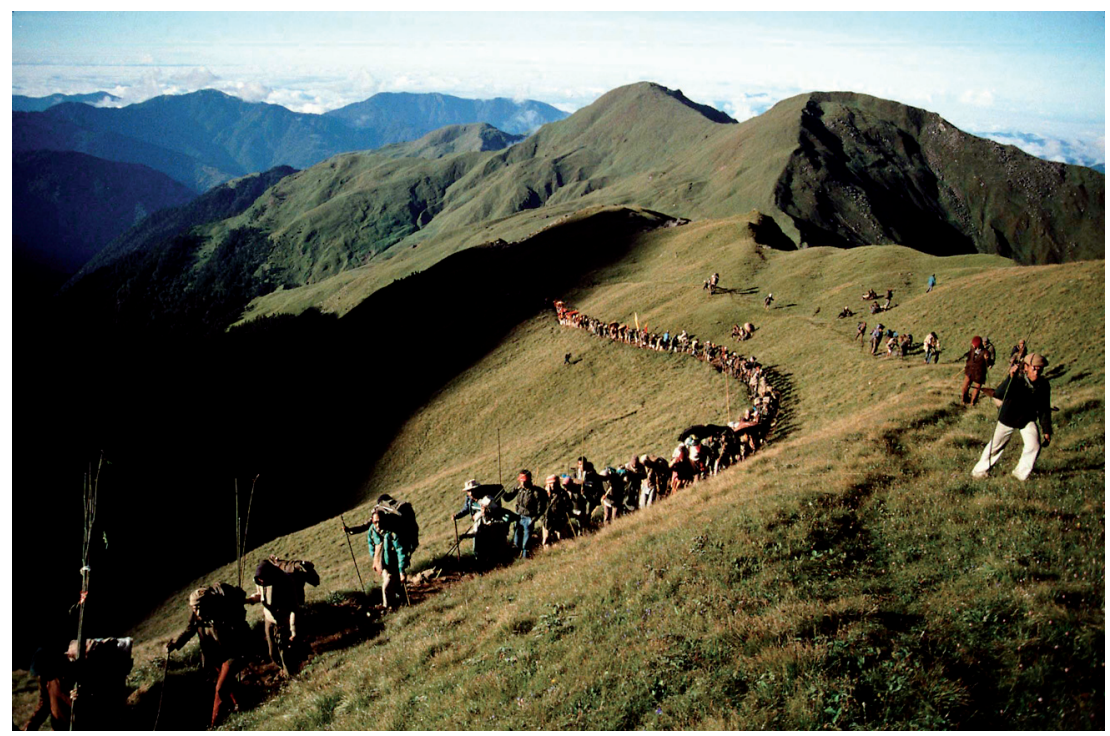

The 1987 Royal Procession, just below Kailavinayak ridge. Photo $\odot$ William Sax. 
and swallowed up by Rupkund, where their bones may be found even today, 600 years later.

We climbed Jyumra Gali, the 'path of death', the most terrifying part of the entire pilgrimage. It was surmounted by an 18,00o-foot pass, the highest point of the journey. Everyone, from the four-horned ram to the most anonymous pilgrim, dragged themselves over the pass, panting for breath. Behind us was a dizzying drop, straight down to the black waters of Rupkund. In front of us was the awesome vista of high Mount Kailash, and we spent a sleepless night listening to the rumbling of its glaciers. We rose again and climbed even higher, over the glacial rubble and into the freezing heights. We were searching for Homkund, the pilgrims' goal, which is also called Ghumaki, 'the place where one stops wandering. When we finally arrived, it was time to say goodbye to Nanda Devi. The eyes of the Prince and his priests were filled with tears, as they decked the four-horned ram with jewellery and sent it toward Mount Kailash. But it would not go! Time and again it returned to the humans who had fed and comforted it for weeks. Finally, one of the pilgrims carried it a couple of hundred yards up the side of the mountain and left it there. Meanwhile, the rest of the pilgrims turned around and began the long trek home.

Two long, muddy days, and many accidents later, we reached the temple of the mountain god Dyosingh in a grove of cedar trees above the village of Subas. Here, another fierce goddess scolded the exhausted pilgrims. 'This is not a human drama', she screamed, 'this is my pilgrimage!' She told them not to harbour anger in their hearts toward their rivals. 'I have told the Highlanders', she said, 'and by the time you leave, you too will hear of my power.' Indeed we heard: there had been a landslide in the Highlanders' village two days earlier: one of the priest's houses slid down the hill, and his mother was killed. So far as the Lowlanders were concerned, this was poof that Nanda Devi had punished the Highlanders for their arrogance.

Many 'traditions' were broken in the Royal Procession of 1987. One foreigner, two women, and numerous Harijans completed the pilgrimage; the yantra at Jogmaya was not excavated; the reunion of goddesses at Nandabal did not take place; and many other rituals were not performed because of the dispute between the rival factions. But as I discovered by talking with my fellow pilgrims, and listening to the tea shop gossip on my way back to Delhi, the failure of the four-horned ram to climb the mountain was the most disappointing of all. Many people attributed it to the feuding of the priests, saying that they had subordinated dharma to rajniti, that is, that they had subordinated religion to politics. 'Now the Progress is no more', they said, 'and how will its power return?' 


\section{Conclusion: ritual, politics, and pilgrimage}

Obviously a great deal of time, money, and labour are invested in the pilgrimages of Nanda Devi, and in this respect they are similar to ritual processions the world over. Why did the kings of this impoverished Himalayan province devote so many resources to a ritual that, from our perspective, might look like a sheer waste of time? And why did the two factions quarrel so bitterly over the order of the procession? To answer these questions we must overcome a problem that plagues anthropology, and especially the anthropology of religion: the problem of 'symbol-talk. The problem is that in many formulations, the 'symbolic' is actually the 'merely symbolic', and the so-called 'symbolic dimension' of religion and ritual often turns out to be merely an expression or a reflection of more fundamental realities. 'Real' political or economic relations are merely 'symbolized' by religion and ritual, and little or no thought is given to the ways in which ritual and religious action might, in fact, create such realities. Having invoked and dismissed 'the symbolic', the analyst is free to move on to those features he or she considers more basic, which usually turn out to be the great totems of Western social thought: wealth and power.

But ritual processions around the world clearly show us that 'symbolic' behaviour has important political consequences. In ritual processions from a variety of cultures, rulers and other important persons such as party leaders and deities create powerful relationships with territorial and social units by moving through, or across, or around them. Elsewhere in north India, Alan Beals (1964) and Peter van der Veer (1987) have shown how factional political ends are served by the processions of both village gods and Hindu monks, and these politico-ritual journeys are by no means unique to South Asia. Marshall Sahlins (1989) gives an account of the political effects of the annual Makahiki festival of Hawaii, Inga Clendinnen (1980) has described the processions organized by colonial Franciscan missionaries in direct competition with native agricultural gods', and Susan G. Davis (1985) shows the importance of marches and parades to the political life of Philadelphia in the early nineteenth century. In all of these ritual processions, a particular group-it may be a royal entourage, a political candidate, a missionary sector what-have-you-asserts its physical unity with a specific territory by circumambulating or traversing it. And what seems to be a 'symbolic' act comes to have immense political consequences because it is through these kinds of public, collective rituals that societies define themselves to themselves. A private procession would be like a party to which nobody came; it would have few if any social consequences. A candidate for office in Germany or Finland 
must not only shake hands and kiss babies, she must be publicly seen to do so, thereby demonstrating her oneness with 'the people'. To publicly lead the procession, and to be seen to lead it, or define its form, is simultaneously to claim authority over both land and people; it is not a display of 'empty' forms or 'mere' symbols, but rather a powerful kind of political action.

This explains why religious processions are so often associated with violence, in European as well as Asian cultures. Because of the public, self-defining nature of the procession, the stakes are very high, amounting to no less than recognition of the existence of certain groups, along with their economic and political relations with each other and the territories they inhabit. To give an inch is to surrender the group's claims to authority and legitimacy-and that is why, for the Highlanders as well as the Lowlanders, nothing less than their collective prestige was at stake. That is why public marches and processions are banned by totalitarian regimes, which, by monopolizing the power of self-definition, seek to limit their opponents' power. In other words, to control the ritual is to control the definition and constitution of society and the relations between its parts-and what greater power could there be? As Thomas Szasz put it, 'In the animal kingdom, the rule is: eat or be eaten. In the human kingdom, the rule is: define, or be defined' (1974: 20).

\section{References}

\section{Atkinson, Edwin T.}

1974 Kumaun Hills: Its History, Geography and Anthropology with Reference to Garhwal and Nepal. 4 vols. Delhi: Cosmo Publications. (First published in 1882 in Allahabad under the title The Himalayan Districts of the North Western Provinces of India.)

\section{Beals, Alan}

1964 Conflict and Interlocal Festivals in a South Indian Region. Journal of Asian Studies 23: 99-113.

\section{Clendinnen, Inga}

1980 Landscape and World View: the Survival of Yucatec Maya Culture Under Spanish Conquest. Comparative Studies in Society and History 22 (3): 37493.

\section{Dabaral, Shivaprasad}

1965-78 Uttarakhand ka Itihas [History of Uttarakhand]. 8 vols. Dogada, Garhwal: Vir Gatha Prakasan.

\section{Davis, Susan G.}

1985 Popular Uses of Public Space in Philadelphia, 1800-1850. In: Vincent Mosco 
\& Janet Wasko (eds), The Critical Communications Review. Vol 3: Popular Culture and Media Events; pp. 3-23. Norwood, NJ: Ablex.

Gupte, B. A.

1919 Hindu Holidays and Ceremonials with Dissertations on Origin, Folklore and Symbols. (Reprinted as Folklore of Hindu festivals and ceremonials; pp. 180-3. Delhi: Shubhi, 200o.)

Hazra, R. C.

1942 The Devi-Purana. New Indian Antiquary V (April): 2-20.

1962 The Devi Purana, a Work of Bengal. Purana IV (2).

Kielhorn, F.

1896 Pandukesvar Plate of Lalitasuradeva. Indian Antiquary 25: 177-84.

Sahlins, Marshall

1989 Captain Cook at Hawaii. The Journal of the Polynesian Society 98 (4): 371424 .

\section{Sax, William S.}

1991 Mountain Goddess. Gender and Politics in a Himalayan Pilgrimage. New York: Oxford University Press.

\section{Seneviratne, H. L.}

1978 Rituals of the Kandyan State. Cambridge: Cambridge University Press.

Sircar, D. C.

1956 Three Plates from Pandukesvar. Epigraphica Indica 31: 277-98.

1959 Some Inscriptions from UP. Epigraphica Indica 34: 243-54.

Szasz, Thomas

1974 The Second Sin. London: Routledge and Kegan Paul.

Underhill, M. M.

1921 The Hindu Religious Year. Calcutta: Association Press.

Veer, Peter van der

1987 'God Must be Liberated!' A Hindu Liberation Movement in Ayodhya. Modern Asian Studies 21 (2): 283-301. 